\title{
The Effect of Depression on the Quality of Life of Patient with Cervical Cancer at Dr. Moewardi Hospital in Surakarta
}

\author{
Rita Benya Adriani, Martono, Endang Caturini Sulistyowati \\ School of Health Polytechnics, Poltekkes Surakarta
}

\begin{abstract}
Background: The share of cervical cancer of all types of cancer was 37.65\% (9,113 cervical cases of the total 24,204 cancer cases) in Central Java in 2009. Cancer deteriorates physical, psychological, social, and spiritual states of the persons affected, especially in patients of terminal stage. Depression may interfere the quality of life of the affected. This study aimed to determine the effect depression on the quality life of patients with cervical cancer.

Subjects and Method: This was an analytic observational study with cross sectional design. This study was conducted at Dr. Moewardi Hospital, Surakarta, from May to August 2014. A total of 36 patients with cervical cancer at Dr. Moewardi Hospital were selected for this study. The independent variables were age, education, employment status, duration of illness, and depression. The dependent variable was quality of life. The depression was measured by Beck Depression Inventory (BDI). The quality of lifewas measured by European Organization for Research and Treatment of Cancer (EORTC) QOQ-C3O and EORTC QOQ-CX24. The data were analyzed by logistic regression analysis.

Results: After controlling for age, education, employment status, and duration of illness, depression showed strong effect $(\mathrm{OR}=14.83 ; 95 \% \mathrm{CI}=2.29$ to $96.07 ; \mathrm{p}=0.005)$ on the quality of life of patients with cervical cancer. Patients with severe depression were 14.83 times more likely to have poor quality of life than those with moderate or mild depression.

Conclusion: Depression affects the quality of life in patients with cervical cancer. Patients with severe depression were more likely to have poor quality of life than those with moderate or mild depression.
\end{abstract}

Keywords: depression, quality of life, cervical cancer

\section{Correspondence:}

Rita Benya Adriani. School of Health Polytechnics, Poltekkes Surakarta.

Email: benyaadriani@gmail.com. Mobile: 08122617033

\begin{abstract}
BACKGROUND
Cancer strikes at any age, commonly happens at above 65 years old. People with cancer will be physically, psychologically, socially, and spiritually influenced by emotional reactions especially happen on dying patients. There are five emotional reactions namely denial, anger, bargaining, depression, dan acceptance (Kubler, 2003). In addition to the problems above, there is also reproductive disruption, among others is sexual problems.
\end{abstract}

According to Aziz (2005) themost common cancer in Indonesia is cervical cancer in the top rank with 3,686 cases (17.85\%). Meanwhile cervical cancer is the second of the leading causes of death worldwide with approximately 510,000 new cases and 288, 000 of them are dying (Jemal, 2006). According to the data from Indonesia Health Profile 2007 of Department of Health (2008) breast cancer is the first in the list of 10 most common cancers in Indonesia with 8,328 patients (19.64\%), followed by uterine cervical cancer with 4,639 patients (11.07\%). The incidents of cervical cancer in Central Java in 2009 are 9,113 cases (37.65\%) out of 24,204 cases of 
cancers (Central Java Health Profile, 2009). It can be concluded that cervical cancer is the second most common disease after breast cancer however it is the second of the leading causes of all deaths.

Cervical cancer issue will disturb the sustainability of harmony especially in the sexual relationship, thus the patients with cervical cancer will feel fear, anxiety, and sadness in their family life. Anxiety disorder is not only experienced by patients with cervical cancer, but also undergone by women, individual less than 45 years old, individual who is divorced and individual who comes from lower social economy status (Videbeck, 2008). Based on the above description, cervical cancer may cause disharmony between husbands and wives and may result in distance in their sexual relationships, it may generate the feeling of sad, anxious, and worry to wives.

Fear of cancer is very common, it is reminiscent of entering death slowly, and patients undergo severe psychological reactions, that are related to age, cultural level, life experience, and awareness on medical knowledge (Desen, 2008). Individuals who are at high risk of depression are those who endure chronic physical health problems/ disorders (Varcarolis, 2006), such as neurology, endocrine, metabolism/ nutrition, chronic infection, and other chronic diseases.

Depression which is one of mental health disorders especially mood disorder can disturb individual life. Individuals are afflicted by long term, drastic, and agitating distress, followed by self-doubt, guilt, and anger that may change their activities in life especially which involves self-esteem, occupations, interpersonal relationship (Videbeck, 2001). The conditions above may influence one's life quality since it can change people especially in her working activity, communicating with others and it also lower down her self-esteem.

Quality of life is something subjective, multidimensional experience of welfare which is culturally built in finding individual safety and security, the feeling of integrity and the meaning of life, also the sense of belonging in social network (Singer, 2010). Health condition which is related to quality of life and psychosocial function in cancer patients is linked to objective clinical symptoms, the ability to adjust toward the disease and treatment, also patients' satisfaction toward healthcare service (Essen, 2002).

Based on the above description, researchers conducted a study entitled "Depression on cervical cancer patients in its relation with the quality of life in DR. Moewardi Regional General Hospital in Surakarta"

\footnotetext{
SUBJECTS AND METHOD

This was a correlational descriptive study with cross sectional design. Study design describes research problems based on the distribution and then finds the relation between one with another variables.

The study was conducted in The study was conducted in May-August, 2014, at Dr. Moewardi Hospital, Surakarta, Central Java. The population of the study were patients of cervical cancer in DR Moewardi Hospital Surakarta. A total of 36 sample were collected by total sampling technique. Those entire population members are made into sample.

The research variable in this research were depression condition as free variable and quality of life as bound variable, whereas confounding variables were age, occupations, patients' last education, marital status, fund source, and illness duration.
} 
Research instrument used for the depression condition of patients is Depression questionnaire (My current condition), that is about depression scale which is the result of modification (Kristyaningsih, 2009) from Beck Depression Inventory (BDI) Screening Test which consists of 21 questions. Depression condition was obtained by summing up all respondents' answers and the result was divided into 2 data categories during data processing, based on mean which was obtained according to data processing, that $\leq 24$ was categorized of nondepression and $>24$ was categorized as depression. Quality of life questionnaire was taken from European Organization for Research and Treatment of Cancer (EORTC) QOQ-C30 (Version 3.0) with prior consent.

Life quality of a patient which represents one's health impression consists of physical, role, emotional, cognitive, social, and global function. The questionnaire consisted of 30 items including 14 questions about physical function. The assessment was conducted by calculating the value of 1 up to 4 where $1=$ none, $2=$ a little, $3=$ quite a little, $4=$ very much. The research result was classified into 2 data categories based on mean value. Based on data processing, the result of mean was as follow: $\leq 103$ was categorized as qualified, whereas $>103$ was categorized unqualified.

Data analysis was including univariate that descriptively analyzed the existing variables by calculating frequency and proportion distribution. The analysis was conducted toward each research variable. In this part the variables being analyzed were education, age, occupation, fund source, marital status, illness duration, depression condition, and life quality. Bivariate analysis was analysis conducted toward 2 variables that were suspected to be connected or correlated.
In this research bivariate analysis was used to know the relationship between each independent variable that was depression condition with dependent variable that was life quality. In this research data analysis used was Chi Square test $\left(\mathrm{X}^{2}\right)$, since the data in this research was in a form of categories (ordinal and nominal).

The statement was in accordance with Hastono's statement (2007) that statistical test for data in a form of categories can use Chi Square $\left(\mathrm{X}^{2}\right)$. Multivariate Analysis was used to prove the formulated hypothesis and to seek components (depression condition and characteristics) which were the most dominantly related toward life quality. It was conducted by analyzing simple regression correlation test.

\section{RESULTS

a. Characteristics of the research
subjects

Characteristics of the respondents can be seen in Table 1. Table 1 presents the characteristics of cervical cancer patients consisted of age of the research subjects was around 50 years old. Educational background of the most of research subjects was elementary school as many as 27 people (75\%), meanwhile there were 9 people (25\%) whose educational level was above elementary school. Most of the research subjects were unemployed, as many as 22 people $(61.1 \%)$, whereas there were 14 research subjects (38.9\%) who were employed.

According to treatment duration most of the research subjects who were 23 people (63.9\%) spent $\leq 12$ days of treatment, meanwhile there were 13 people $(36.1 \%)$ who spent $>12$ days of treatment. Number of research subjects who did not endure depression was 21 people (58.3\%). Subjects who endured depression were 15 people (41.7\%). Based on life quality, most of the 
research subjects, as many as 21 people (58.3\%), possessed life quality. Whereas there were 15 people (41.7\%) who did not have life quality.

Table 1. Frequency distribution of research subjects in Dr. Moewardi Regional General Hospital Surakarta

\begin{tabular}{lccc}
\hline \multicolumn{1}{c}{ Characteristics of Social Demography } & n & \% \\
\hline Age & $\geq 5$ o years & 17 & $47.2 \%$ \\
Last education & $<5$ years & 19 & $52.8 \%$ \\
\multirow{2}{*}{ Occupation } & < elementary school & 27 & $75 \%$ \\
& $\geq$ elementary school & 9 & $25 \%$ \\
Treatment Duration & unemployed & 22 & $61.1 \%$ \\
& employed & 14 & $38.9 \%$ \\
Depression & $\geq 12$ days & 13 & $36.1 \%$ \\
& <12days & 23 & $63.9 \%$ \\
Life Quality & Severe & 15 & $41.7 \%$ \\
& Mild/ Moderate & 21 & $58.3 \%$ \\
& Less/ Poor & 15 & $41.7 \%$ \\
& Good & 21 & $58.3 \%$ \\
\hline
\end{tabular}

b. The relation between depression condition of cervical cancer patients with life quality

Table 2. The relation of depression condition of cervical cancer patients with life quality in Dr. Moewardi Regional General Hospital, Surakarta

\begin{tabular}{|c|c|c|c|c|c|c|c|}
\hline \multirow{3}{*}{\multicolumn{2}{|c|}{ Variable }} & \multicolumn{4}{|c|}{ Life Quality } & \multirow{3}{*}{ OR } & \multirow{3}{*}{$\mathbf{p}$} \\
\hline & & \multicolumn{2}{|c|}{ Less/ Poor } & \multicolumn{2}{|c|}{ Good } & & \\
\hline & & $\mathbf{n}$ & $\%$ & $\mathbf{n}$ & $\%$ & & \\
\hline \multirow[t]{2}{*}{ Depression } & Severe & 11 & 73.3 & 4 & 26.7 & 11.69 & 0.004 \\
\hline & Mild/ Moderate & 4 & 19 & 17 & 81 & & \\
\hline
\end{tabular}

c. Factors related to quality of life

Table 3. Factors related to less/poor quality of life on cervical cancer patients of Dr. Moewardi Regional General Hospital Surakarta

\begin{tabular}{lrrrr}
\hline & OR & \multicolumn{2}{c}{$\mathbf{9 5 \%}$ CI } & \multirow{2}{*}{$\mathbf{p}$} \\
\cline { 2 - 4 } & & Lower Limit & Upper Limit & \\
Age $\geq$ 50 years & 0.81 & 0.13 & 4.94 & 0.816 \\
Education < Elementary & 1.24 & 0.16 & 9.49 & 0.834 \\
School & & & & \\
Unemployed & 2.57 & 0.35 & 18.72 & 0.352 \\
Treatment duration $\geq 12$ days & 0.25 & 0.03 & 2.02 & 0.193 \\
Severe depression & 14.83 & 2.29 & 96.07 & 0.005
\end{tabular}

$\mathrm{N}$ observation $=36$

Table 2 show the result obtained, that research subjects without depression who experienced unqualified life as cervical cancer patients are $19 \%$ meanwhile those who experienced qualified life are $81 \%$. Research subjects with depression who experienced unqualified life are $73.3 \%$, mean while those who experienced qualified life are $26.7 \%$.

From statistic calculation using Pearson Chi Square the result obtained for the life of patients with cervical cancer is $\mathrm{p}=0.004$, therefore it was notified that there was significant relationship between 
depression condition of cervical cancer patients with quality of life.

Table 3 showed the obtained result that depression is a dominant factor related to the patients' quality of life with $\mathrm{p}=$ 0.005 , by OR of depression variable is 14.83 which means that respondents with cervical cancer who endured depression would experience poor quality of life 15 times higher compared to cervical cancer patients who do not endure depression, after being control by variables of age, education, occupation, and treatment duration.

\section{DISCUSSION \\ a. Respondents' Characteristics \\ In this study research subjects were around 50 years old. There were 19 (52.8\%) study subjects who were less than and equal to 50 years old. It happened because of degene- rative in the age of 50, as it is conveyed by Vignaroli (2006) that age is one of factors that influence depression level on cancer patients.}

1) Most of the study subjects' educational level was elementary school, there were 27 people (75\%). Vignaroli (2006) said that education is one of factors that influence depression level on cancer patients.

2) Most of the study subjects were unemployed, there were 22 people (61.1\%). Vignaroli (2006) conveyed that occupation is one of factors that influence depression level of cancer patients.

3) In this study the treatment duration was around 12 days of treatment. Most of the duration was less than and equal to 12 days, that were as many as 23 people (63.9\%). It is in accordance with Prina (2012) that the treatment duration of cancer patients will influence one's depression.

\section{b. Depression Condition}

Most of the research subjects did not endure depression were 21 people (58.3\%), whereas subjects who endured depression were 15 people $(41.7 \%)$. It was opposing with the research result of Yang (2014) that prevalence in cervical cancer is $52 \%$. It is also conveyed by Prina (2012) that patients' treatment duration will influence one's depression.

\section{c. Quality of Life}

Most of study subjects, as many as 21 people (58.3\%) possessed quality of life. Meanwhile, study subjects who did not have quality of life were 15 people (41.7\%). It was similar with what Singer (2010) conveyed that quality of life is something subjective, multidimensional experience from the welfare which is culturally built in finding for individual safety and security, sense of integrity and the meaning of life as well sense of belonging within a social network.

Chui (2009) conveyed the same idea as well that quality of life is a subjectivity of patients' perspective and multidimensional than refer to different assessment of patients' life including physical welfare, functional, emotional, and social. Also stated by Skarstein (2002) and singer (2010) that quality of life is something subjective, multidimensional experience from welfare which is culturally built as the finding for individual safety and security, sense of integrity and the meaning of life as well as sense of belonging within a social network.

\section{d. Relationship between depression condition cervical cancer patients with quality of life.}

Table 2 presents the obtained result that research subjects without depression who experienced unqualified life on cervical cancer patients were $19 \%$, meanwhile those who experienced qualified life were $81 \%$. Research subjects with depression who experienced unqualified life on cervical cancer patients were $73.3 \%$, meanwhile 
those who experienced qualified life were $26.7 \%$. The same statement was also conveyed by Yang (2014) the occurrence of depression will reduce quality of life of cervical cancer patients.

From the result of statistical test using Pearson test Chi Square obtained $\mathrm{p}=$ 0.004 , so that it was stated that there was significant relationship between depression condition of cervical cancer patients and quality of life. It was also stated by Akashiba (2002) that there is a relationship between depression and quality of life.

\section{e. Dominant factors that was related to quality of life}

Depression was a dominant factor that was related to patients' quality of life with $\mathrm{p}=$ 0.005 , with OR from depression variable was 14.83 , it means that research subjects who experienced depression would likely endure poor quality of life as much as 15 times higher compared to cervical cancer patients who did not experience depression after being controlled by variables of age, education, occupation, and duration of treatment.

Itwasalso supported by Essen (2002), who stated that quality of life influenced by patients characteristics that consisted of factors of physical, psychological, sociocultural, and spiritual, namely age, marital status, occupation, poverty (Radwin, 2003), education, duration of illness (Ahlner, 2009), norms, values, purpose, expectation, religion, religiosity, faith, and family support (Tsujikawa, 2009)

Similarly, quality of life was multidimensional concept that was defined as one's perception about situation of life in its relation with culture, values, welfare, economy, and accommodation (Songhuai, 2009).

From this research it can be concluded that characteristics of cervical cancer patients in Dr. Moewardi Regional General Hospital were around 50 years old, dominated by elementary school as their educational background, unemployed with 12 days of treatment. For depression condition, most of patients did not experience depression. Most respondents possessed quality of life. The depression condition of cervical cancer patients had a relation with quality of life.

Dominant factors that contributed with patients' quality of life was depression, that cervical cancer respondents who endured depression would likely to experience poor quality of life higher compared to cervical cancer patients who did not endure depression after being controlled by variables of age, education, occupation, and duration of treatment.

\section{REFERENCE}

Akashiba T, Kawahara S, Akahoshi T, Omori C, Saito O, Majima T, Horie T (2002). Relationship between quality of life and mood or depression in patients with severe obstructive sleep apnea syndrome. Journal Chest 122: 3.

Amalia L (2009). Mengobati Kanker Serviks dan 32 jenis Kanker lainnya. Yogyakarta: Landscape.

Arraras JI (2008). The EORTC of Life Questionnaire QLQ-C30 (Verson 3.0). Validation study for Spanish Prostate Cancer Patients: International Section Arch Esp Urol 61(8): 949-954.

Aziz MF (2005). Vaksin Human Papillomavirus: Suatu alternatif dalam pengendalian kanker serviks di masa depan. Disampaikan dalam pidato Pengukuhan sebagai Guru Besar tetap dalam Obstetri dan Ginekologi. Jakarta: FKUI. 
Beck A (1985) Depression Cause and Treatment. Philadelphia: University of Pensylvania.

Baradero M, Dayrit MW, Siswadi Y (2008). Seri Asuhan Keperawatan Klien Kanker. Jakarta: EGC.

Brazier JE, Harper R, Jones NMB, O'Cathain A, Thomas KJ, Usherwood T, Westlake L (1992). Validating the SF-36 health survey questionnaire: New outcome measure for primary care. British Medical Journal 305: 160 -164 .

Byock M (1998). Measuring quality of life of life for patients with terminal illness: the Missoula-VITAS Versi-25S quality of life index. Palliat Mede 12;231 Sage.http://www.sagepublications.co $\mathrm{m}$.

Chui YY, Donoghue J, Chenoweth (2005). Responses to advanced cancer: Chinese Australians. Journal of Advanced Nursing 52 (5): 498-507.

Departemen Kesehatan RI (2007). Kepmenkes RI No 812 Tentang Kebijakan Perawatan Paliatif. Jakarta. (2008). Profil Kesehatan Indonesia tahun 2007. Jakarta.

Dinas Kesehatan Provinsi Jawa Tengah (2009). Profil Dinas Kesehatan Provinsi Jawa Tengah Tahun 2009.

DesenW (2008). Onkologi Klinis. Jakarta: Fakultas Kedokteran Universitas Indonesia.

Dewolf L, Groenvold M, Petersen MA (2006). EORTC QLQ-C30. http://www.eortc.be/home/qol/.

Elmqvist MA, Bjordal K, Jordhey MS, Kaasa S, Jannert M (2009). Characteristics and implications of attrition in health-related quality of life studies in palliative care. Palliative Medicine 23: 432-440.
Eortc Quality of life Group (2003). QLQCX24.http://www.group s. Eortc.be/qol/qolg_activities.htm.

Essen LV (2002). Satisfaction with care: associations with health-related quality of life and psychososial fuction among Swedish patients with endocrine gastrointestinal tumours. European Journal of Cancer Care 11:91-99.

Ferrell BR, Coyle N (2010). Oxford Textbook of Palliative Nursing. $3^{\text {rd }}$ ed. Oxford Univercity Press, Incorporated.

Ferrell BR, Grant M (2010). National Medical Center and Beckman Research Institute Quality of Life Patient/ Cancer Survivor Version: http://prc. coh.org/QOL-CS.pdf.

Hastono SP (2007). Analisis data Kesehatan. Tidak Dipublikasikan, Depok.

Jemal A, Siegel R, Ward E (2006). Center Statistics. CA Cancer J Clin 56: 106130.

Kaasa S, Loge JH (2003). Quality of life in Palliative Care: Principles and Practice. Palliative Medicine 17: 11-20. Trondheim: Norway

Kuuble-Ross E (2003). On Death and Dying. What the dying have to teach doctors, nurses, clergy and their own families. New York: Scribner.

Machsoos (2009). Ilmu Penyakit Dalam Pendekatan Diagnostik Tumor Padat. Jakarta: Interna Publishing.

Meneses K, Benz R (2010). Quality of Life in Cancer Survivorship: 20 Years Later. Seminars in Oncology Nursing, 26 (1): 36-46.

Nursalam (2008). Konsep dan Penerapan Metodologi Penelitian Ilmu Keperawatan.Edisi 2. Jakarta: Salemba Medika.

Nursalam, Patriani S (2001). Pendekatan Ptaktis Metodologi Riset Keperawatan. Jakarta: CV Sagung Seto. 
PrinaA M, Huisman M, Yeap BB, Hankey GJ, Flicker L, Brayne C (2012). Association berween depression and hospital outcomes among older men. Journal Canadian Medical Association 12.

Radwin LE (2003). Cancer Patients' Demographic Characteristics and Ratings of PatientCentered Nursing Care. Journal of Nursing Scholarship, 35:4, 365-370.

Rahmawan A (2004). Kualitas Hidup Penderita Karsinoma Nasofarins Pascaterapi, Tesis. Fakultas Kadokteran UGM, Yogyakarta.

Rasjidi I (2010). Perawatan Paliatif Suportif dan Bebas Nyeri pada Kanker. Jakarta: Sagung Seto. (2007). Panduan Penatalaksanaan Kanker ginekologi. Jakarta: EGC.

Robbins SL, Kumar V, Cotran RS (2007). Buku Ajar Patologi Volume I Edisi 7. Jakarta: EGC.

Schulmeister L, Quiett K, Mayer K (2005). Quality of Life, Quality of Care, and Patient Satisfaction: Perceptions of Patients Undergoing Outpatient Stem Cell Transplantation. Oncology Nursing Forum 32(1).

Singer MJ, Padilla GV, Kimlin AG (2010). Health- Related Quality of Life and Culture.Seminar in Oncology Nursing 26(1): 59-67.

Skarstein J, Dahl JL, Fossa SD (2002). Patient Satisfaction in Hospitalized Cancer Patients. Acta Oncologica, 41 (7/8): 639-645.

Smeltzer S, Bare BG (2002). Buku Ajar Keperawatan Medikal-Bedah Brunner \& Suddarth 1 (8). Jakarta: EGC.

Songhuai L, Olver L, Jianjun L, Genlin L, Wilson US (2009). A comparative review of life satisfaction, quality of life and mood between Chinese and British people with tetraplegia. Spinal Cord 47: 82-86.

Sudoyo AW (2009). Buku Ajar Ilmu Penyakit Dalam. Jakarta: Internal Publishing.

Sukardja IDG (2000). Onkologi Klinik. Ed 2. Surabaya: Airlangga University.

Testa MA, Simonson DC (1996). Assessment of Quality-of-Life Outcomes. The England Journal of Medicine 13 (334): 835-840.

Tsujikawa M, Yokoyama K, Urakawa K, Onishi K (2009). Reliability and validity of japanese version of the McGill quality of life questionairre assessed by application in palliative care wards. Palliative Medicine 23: 659664.

Varcarolis EM, Carson VB, Shoemaker NC (2006). Foundations of psychiatric mental Health Nursing: A Clinical approach ( 5 ed) St. Louis: Elservier.

Videbeck SL (2008). Keperawatan Jiwa. Jakarta: EGC.

Ware JE, Sherbourne CD (1992). The MOS 36 Item Short Form Healty Survey (SF-36). I Conceptual Framework \& Item Selection. Med Care 30 (6): 473 -483 .

Yang YL, Liu, Wang XX, Wang Y, Wang L (2014). Prevalence\& Associated Positive Psychological Variables of Depression and anxiety among Chinese Cervical Cancer Patients: a Cross Sectional Study. Plos One 9 (4). 